\title{
Salt stress Tolerance of Methylotrophic Bacteria Methylophilus sp. and Methylobacterium sp. Isolated from Coal Mine Spoils
}

\author{
DEEN DAYAL GIRI ${ }^{2}$, AJAY KUMAR ${ }^{1}$, PRABHU NATH SHUKLA ${ }^{1}$, RITU SINGH $^{1}$, P.K. SINGH ${ }^{1}$ \\ and KAPIL DEO PANDEY ${ }^{1 *}$ \\ ${ }^{1}$ Department of Botany, Banaras Hindu University, India \\ ${ }^{2}$ Department of Chemical Engineering and Technology, Indian Institute of Technology (BHU)
}

Submitted 25 December 2012, revised 21 March 2013, accepted 15 July 2013

\begin{abstract}
Two methylotrophic strains of Bina coalmine spoil BNV7b and BRV25 were identified based on physiological traits and 16S rDNA sequence as Methylophilus and Methylobacterium species. The strains exhibited similar carbon utilization but differed in $\mathrm{N}$ utilization and their response to the metabolic inhibitors. Methylophilus sp. was less tolerant to salt stress and it viability declined to one tenth within $4 \mathrm{~h}$ of incubation in $2 \mathrm{M} \mathrm{NaCl}$ due to membrane damage and leakage of the intracellular electrolytes as evident from malondiaaldehyde (MDA) assay. In $200 \mathrm{mM} \mathrm{NaCl}$, they exhibited increased superoxide dismutase (SOD), catalase (CAT) and ascorbate peroxidase (APX) activity while in $500 \mathrm{mM} \mathrm{NaCl}$, enzyme activities declined in Methylophilus sp. and increased in Methylobacterium sp. Among exogenously applied osmoprotectants proline was most efficient; however, polyols (mannitol, sorbitol and glycerol) also supported growth under lethal $\mathrm{NaCl}$ concentration.
\end{abstract}

Ke y words: Methylophilus sp., Methylobacterium sp., salt stress tolerance

\section{Introduction}

Approximately 397 m.h.a. (million hectares) unproductive saline soils are required to be reclaimed at the global level (FAO, 2006). In saline soil, agricultural productivity is affected due to excessive ions concentration which interferes with plant water uptake leading to physiological and metabolic dysfunctions, Available plant nutrients also get adversely affected since salinity influences microbe mediated soil $\mathrm{C}$ and $\mathrm{N}$ mineralization processes as excessive salt inhibits microbial growth mainly due to ion toxicity (Pathak and Rao, 1998). Under osmotic stress, reactive oxygen species (ROS) such as superoxide radicals, hydrogen peroxide $\left(\mathrm{H}_{2} \mathrm{O}_{2}\right)$ and hydroxyl radicals $(\mathrm{OH})$ are generated in microbes causing oxidative damage of their various cellular components and biomolecules (Halliwell and Gutteridge, 1986). To cope with ROS caused injury, enzyme super oxide dismutase (SOD) gets induced and catalyzes dismutation of $\mathrm{O}_{2}$ to $\mathrm{H}_{2} \mathrm{O}_{2}$ which is further scavenged by catalase (CAT), ascorbate peroxidase (APX) and other enzymes (Gómez et al., 2004). The other adaptive processes developed by microbes to cope with salinity stress include accumulation of protective chemical substances such as polyamines, polysaccharides, amino acids and its derivatives, other compatible solutes including proline, serine, glutamate, betaine, ectoine and inorganic cations $\left(\mathrm{K}^{+}\right)$that protect bacterial cells from salt stress (Robert et al., 2000; Shamseldin et al., 2006).

Coal mine spoils are characterized by low nutrients and high toxic heavy metals load along with the salinity. Such spoils harbor salt tolerant Gram-positive (Bacillus, Arthrobacter and Corynebacterium) and Gram-negative (Pseudomonas, Alcaligenes, Ralstonia, and Burkholderia) bacterial genera as the dominant microflora (Ellis et al., 2003). Recently, stress tolerant methylotrophic bacterial genera have been reported from such desiccated environment (Giri et al., 2012) that survive by utilizing trace amounts of nutrients and a wide variety of organic compounds for their carbon energy source (Pasamba et al., 2007). These methylotrophs play an indispensable role in the ecosystem by active participation in various biogeochemical cycles.

The methylotrophic bacterial genera Methylobacterium sp. and Methylophilus sp. had earlier been employed in metal tolerance, plant growth promotion, plant disease resistance, and soil fertility enhancement

\footnotetext{
* Corresponding author: K.D. Pandey, Algal Research Lab, Department of Botany, Banaras Hindu University, Varanasi-221005, India; phone: 91 9450547298; fax: 91542 6701124; e-mail: kdp_banaras@yahoo.com
} 
(Madhaiyan et al., 2001; Sy et al., 2001; Ivanova et al., 2007). These genera have also been used in industrial production of amino acids, polyhydroxy alkanoates, carotenoids and in bioremediation (Yellore, 1998; Fournier et al., 2005). However, these genera have not been studied in relation to their physiological and biochemical response to salt stress and till now. The knowledge of their salt stress responses could be applied in innovative designing of gene expression systems to augment the microbe mediated soil bioremediation, industrial application as well as in saline soil reclamation. In the present study the two bacterial isolates of coal mine spoil BNV-7b (Methylophilus sp.) and BRV-25 (Methylobacterium sp.) were tested for their physiological and biochemical responses to lethal salt concentrations.

\section{Experimental}

\section{Materials and Methods}

Study site and soil analyses. Soil samples were collected from a two year old coal mine dumping site of Bina in the Sonbhadra district of Uttar Pradesh $\left(24^{\circ} 11^{\prime} \mathrm{N}, 82^{\circ} 38^{\prime} \mathrm{E}\right)$, India Soil texture, bulk density and water holding capacity along with the other physiochemical properties like $\mathrm{pH}$, ammonium-N, nitrate- $\mathrm{N}$, organic $\mathrm{C}$ and total $\mathrm{N}$ were described earlier (Giri et al., 2012). The soil cations $\left(\mathrm{Na}^{+}, \mathrm{K}^{+}\right.$and $\left.\mathrm{Ca}^{+2}\right)$ were extracted in ammonium acetate solution by repeated leaching (Simard, 1993), and their concentrations were determined by Atomic Absorption Spectrophotometer (Perkin-Elmer-167, USA).

Bacterial isolation and identification. From the above mentioned soil, putative methylotrophic bacteria were isolated by plating serially diluted soil suspension $\left(10^{-1}\right.$ to $\left.10^{-6}\right)$ on nitrate mineral salt (NMS) agar containing per litre $\mathrm{Na}_{2} \mathrm{HPO}_{4} 0.036 \mathrm{~g}, \mathrm{KH}_{2} \mathrm{PO}_{4} 0.014 \mathrm{~g}$, $\mathrm{MgSO}_{4} \cdot 7 \mathrm{H}_{2} \mathrm{O} 0.20 \mathrm{~g}, \mathrm{CaCl}_{2} \cdot 2 \mathrm{H}_{2} \mathrm{O} 0.20 \mathrm{~g}, \mathrm{FeSO}_{4} \cdot 7 \mathrm{H}_{2} \mathrm{O}$ $0.005 \mathrm{~g}$, and $1 \mathrm{ml}$ of trace elements stock $\left(\mathrm{Na}_{4} \mathrm{EDTA}\right.$ $0.00 \mathrm{gl}^{-1}, \mathrm{ZnSO}_{4} \cdot 7 \mathrm{H}_{2} \mathrm{O} 0.007 \mathrm{gl}^{-1}, \mathrm{MnCl}_{2} \cdot 4 \mathrm{H}_{2} \mathrm{O} 0.030 \mathrm{gl}^{-1}$, $\mathrm{H}_{3} \mathrm{BO}_{3} 0.03 \mathrm{gl}^{-1}, \mathrm{CoCl}_{2} \cdot 6 \mathrm{H}_{2} \mathrm{O} 0.20 \mathrm{gl}^{-1}, \mathrm{CuCl}_{2} \cdot 2 \mathrm{H}_{2} \mathrm{O}$ $0.001 \mathrm{gl}^{-1}$ ) supplemented with $0.5 \%$ methanol under standard microbiological conditions (Hanson, 1998). The bacterial isolates were maintained in bacteriological incubator $\left(30^{\circ} \mathrm{C}\right)$ on NMS agar slant and broth. Exponentially growing bacterial culture $(0.1 \mathrm{ml})$ was inoculated in culture tubes containing $9.9 \mathrm{ml}$ NMS medium with a specific salt concentration and growth was measured in terms of optical density $\left(\mathrm{OD}_{600}\right)$ at $72 \mathrm{~h}$ intervals for 12 days using spectrophotometer (Systronics-117, India). The effect of methanol $(0.001$ to $10 \%)$ as the $\mathrm{C}$ source was checked at the same inoculation period.

Bacterial isolates were taxonomically characterized by amplifying, sequencing and analyzing the $16 \mathrm{~S} r$ RNA as described earlier (Giri et al., 2012). A phylogenetic tree was constructed using MEGA 4.1 program with the neighbor-joining $(\mathrm{N}-\mathrm{J})$ method based on a matrix of distances.

Effect of $\mathrm{NaCl}$ on growth. Log phase methylotrophic strains $\left(\mathrm{A}_{600}=0.5\right.$ to 0.6$)$ were inoculated into $50 \mathrm{ml}$ of fresh NMS medium containing $\mathrm{NaCl}$ (100, 200 and $500 \mathrm{mM})$ and specific growth rate $\left(\mu\right.$ day $\left.^{-1}\right)$ was calculated on the basis of $\left(\mathrm{OD}_{600}\right)$ at various time intervals following Myers and Kratz (1955) using the formula

$$
\mu=\left\{2.303\left(\log \mathrm{N}_{2}-\log \mathrm{N}_{1}\right)\right\} / \mathrm{T}_{2}-\mathrm{T}_{1},
$$

Where $\mathrm{N}_{1}$ and $\mathrm{N}_{2}$ are the $\mathrm{OD}_{600}$, at time $\mathrm{T}_{1}$ and $\mathrm{T}_{2}$, respectively.

Estimation of $\mathrm{Na}^{+}$. Intracellular $\mathrm{Na}^{+}$was estimated in cell biomass grown for $4 \mathrm{~h}$ in $200 \mathrm{mM}$ and $500 \mathrm{mM} \mathrm{NaCl}$ following Li and El-Mallakh (2004). The time course of $\mathrm{Na}^{+}$uptake was studied only in culture medium with $200 \mathrm{mM} \mathrm{NaCl}$. Samples were withdrawn at regular time intervals and cell biomasses were harvested. Cell pellets were washed three times with isotonic $\mathrm{MgCl}_{2}$ solution (100 mM) and lysed overnight with $30 \% \mathrm{HNO}_{3}$. $\mathrm{Na}^{+}$was measured by using flame atomic absorption spectrophotometer (Perkin-Elmer-167, USA) with lamp current (8 mA), wavelength $(589.0 \mathrm{~nm})$, and slit width $(0.4 \mathrm{~nm})$. All the samples were prepared in Milli 'Q' water and various $\mathrm{NaCl}$ concentrations $(0.1,0.5$, and $1 \mu \mathrm{M})$ were used for preparation of standard curve.

Assay of antioxidative enzymes. To study the salt induced antioxidative enzymatic activity in the bacteria, cell homogenate was extracted in $50 \mathrm{mM}$ phosphate buffer (pH 7.0), containing 1 mM EDTA, Triton X-100 $(0.05 \%), 2 \%(\mathrm{w} / \mathrm{v})$ polyvinyl pyrrolidone (PVP) and $1 \mathrm{mM}$ ascorbic acid. The SOD activity was measured as inhibition of photochemical reduction of nitro blue tetrazolium (NBT) at $560 \mathrm{~nm}$ in a $3 \mathrm{ml}$ reaction mixture followed by illumination under a fluorescent lamp for 15 min (Beauchamp and Fridovich, 1971). An illuminated blank without cell free extract, gave the maximum reduction of NBT on the basis of $\mathrm{OD}_{560}$. Further, an unilluminated blank without cell free extract was used as the reference. SOD activity was expressed as $\mathrm{U} \mu \mathrm{g}$ protein $^{-1}$.

Catalase (CAT) activity was measured following the method described by Clairbone (1985). For its estimation, decrease in $\mathrm{H}_{2} \mathrm{O}_{2}$ absorbance was measured by scanning the $2 \mathrm{ml}$ assay mixture at $240 \mathrm{nM}$ for one minute. The extinction coefficient for catalase was $0.039 \mathrm{mM} \mathrm{cm}^{-1}$ and the activity was calculated as mol min $^{-1}$ g protein ${ }^{-1}$.

APX activity was measured as the decrease in absorbance of $\mathrm{H}_{2} \mathrm{O}_{2}$ at $290 \mathrm{nM}$ as described by Asada (1984). The $1.2 \mathrm{ml}$ reaction mixture was scanned for one minute in spectrophotometer. The extinction coef- 
ficient was $2.8 \mathrm{mM} \mathrm{cm}^{-1}$ for APX and the activity was

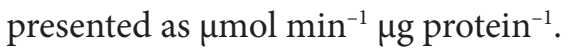

Peroxide assay. Peroxide content was measured following Sagisaka (1976). In brief, bacterial cell were harvested, suspended in cell lysis buffer and sonicated for 15 minutes followed by addition of TCA (20\%). Resulting suspension was centrifuged and supernatant $(1.6 \mathrm{ml})$ was added into reaction mixture $(0.4 \mathrm{ml}$ of $50 \%$ TCA, $0.4 \mathrm{ml}$ of $10 \mathrm{mM}$ ferrous ammonium sulfate and $0.2 \mathrm{ml}$ of $2.5 \mathrm{M}$ potassium thiocyanate), centrifuged and the $\mathrm{OD}_{480}$ of supernatant was compared with standard curve for measuring the concentration of $\mathrm{H}_{2} \mathrm{O}_{2}$.

Lipid peroxidation. Oxidative damage of lipid was estimated indirectly by measuring the total content of 2-thiobarbituric acid (TBA) reactive substances and expressed as equivalent of MDA (malondialdehyde) as described by Cakmak and Horst (1991). In brief, bacterial culture $(1.0 \mathrm{ml})$ was mixed with $1.0 \mathrm{ml}$ of $20 \%(\mathrm{w} / \mathrm{v})$ trichloroacetic acid (TCA) centrifuged $(10,000 \times \mathrm{g}$, for $10 \mathrm{~min}$ at $4^{\circ} \mathrm{C}$ ) and supernatant was suspended in $0.5 \mathrm{ml}$ of Phosphate buffer saline followed by the addition of TBA $(1.0 \mathrm{ml}$ of $0.67 \%)$ and incubated at $90^{\circ} \mathrm{C}(20 \mathrm{~min})$. The reaction stopped in ice-bath and $\mathrm{OD}_{532}$ was compared using culture medium as the blank. MDA concentration was calculated based on a standard curve of 1, 1, 2, 3-tetramethoxypropane.

Electrolyte leakage. Electrolyte leakage was measured as described by Lutts et al. (1996). Cell pellets of bacteria grown in 200 and $500 \mathrm{mM} \mathrm{NaCl}$ were washed thrice with deionized water to remove the surfacebound electrolyte, suspended in $10 \mathrm{ml}$ of Milli 'Q' water and incubated on shaker $\left(120 \times \mathrm{g}, 30^{\circ} \mathrm{C}, 24 \mathrm{~h}\right)$. Electric conductivity of the suspension solution was determined before $\left(E C_{1}\right)$ and after $\left(E C_{2}\right)$ steam sterilization at $120^{\circ} \mathrm{C}$ for 20 minutes using conductivity meter (Systronics, India). Electrolyte leakage is defined as:

Electrolyte leakage $(\%)=\left(\mathrm{EC}_{1} / \mathrm{EC}_{2}\right) \times 100$.

Organic solute leakage. Carbohydrate content was determined by Yemm and Willis (1954). Alcoholic extract of cell pellet $(0.1 \mathrm{ml})$ mixed with $3 \mathrm{ml}$ freshly prepared anthrone reagent $(150 \mathrm{mg}$ anthrone and $100 \mathrm{ml} 72 \% \mathrm{H}_{2} \mathrm{SO}_{4}$ ), placed in a boiling water bath for 10 min reaction was terminated on ice, and $\mathrm{OD}_{625}$ was compared with D-Glucose standard curve for concentration measurement of carbohydrate. Total amino acid content was estimated by Moore and Stein (1948) and total protein content by Bradford (1976). To estimate carotenoids content, a known volume of bacterial culture was centrifuged and the pellet was incubated overnight in $5 \mathrm{ml}$ acetone $(80 \% \mathrm{v} / \mathrm{v})$ at $4^{\circ} \mathrm{C}$, followed by centrifugation and $\mathrm{OD}_{480}$ of supernatant to calculate specific absorption coefficient (Myers and Kratz, 1955). Total RNA content was estimated following the modified orcinol method (Kamali and Manhouri, 1969).
Tetrazolium assay for cell viability. Cell viability against elevated $\mathrm{NaCl}$ concentration was tested by TTC assay (Maness et al., 1999) with some modifications. The exponentially growing cells were harvested by centrifugation $\left(10,000 \times \mathrm{g}, 10 \mathrm{~min}, 4^{\circ} \mathrm{C}\right)$ and pellet were suspended in $5 \mathrm{ml}$ phosphate buffer ( $\mathrm{pH} 7.0$ ) containing $0.12 \%$ TTC and $1.2 \%$ sodium succinate. The pellet in phosphate buffer without TTC and sodium succinate served as a control. The reaction mixture was incubated in the dark $\left(37^{\circ} \mathrm{C}, 4 \mathrm{~h}\right)$. The red formazan formed was extracted in $1 \mathrm{ml}$ acetone and absorbance was measured at $490 \mathrm{~nm}$.

Effect of osmoprotectants. Bacterial cells were inoculated in various flasks containing $50 \mathrm{ml}$ NMS medium having $500 \mathrm{mM} \mathrm{NaCl}$ to study the effect of different osmoprotectants (glycine, betaine, sucrose, proline, mannitol, glycerol and sorbitol) and each osmoprotectant was added at its final concentration of $100 \mathrm{mM}$. Osmoprotective potential of osmolyte was expressed in terms of specific growth rate of the bacterial (something missing).

Chemicals. All the chemicals were of reagent grade from Sigma-Aldrich (USA) or Merck India Ltd. They were filter sterilized through Millipore filter when required (Millipore, India) before use (data not shown).

\section{Results}

Soil properties. The coal mine spoil at the study site was sandy loam, with low water holding capacity, soil organic $\mathrm{C}$ and $\mathrm{t}$ otal $\mathrm{N}$. The soil sample had high levels of exchangeable $\mathrm{Na}^{+} 0.43 \mathrm{mgg}^{-1}, \mathrm{~K}^{+} 0.16$ and $\mathrm{Ca}^{++} 43.1 \mathrm{mgg}^{-1}$.

Bacterial identification. The selected bacterial strains were pink coloured, round shaped and convex elevated colonies and differed only in size. The colonies of strain BNV7b were large $(<1 \mathrm{~mm})$ compared to BRV25 $(0.5-1 \mathrm{~mm})$ on NMS agar medium. The selected strains were similar in their response to urease, catalase, oxidase, indole and $\mathrm{H}_{2} \mathrm{~S}$ production. The details of the phenotypic and biochemical characteristics of these strains have been described elsewhere (Giri et al., 2012). The two strains differed with respect to their organic substrate utilization as Methylophilus BNV7b did not utilize formate and Methylobacterium BRV25 did not utilize citrate as $\mathrm{C}$ source. The former strain did not utilize ammonium acetate, aspartate, cysteine and glutamate as the $\mathrm{N}$ substrate and later strain was unable to utilize alanine, aspartate, glutamate, glycine, isoleucine, lysine, proline and sodium nitrate as $\mathrm{N}$ source. The growth rate of the two strains was fast in $\mathrm{KNO}_{3}$ and arginine supplemented NMS medium. Increase in methanol concentration from $0.1 \%$ to $0.5 \%$ resulted in enhanced the growth; however, a further increase was 


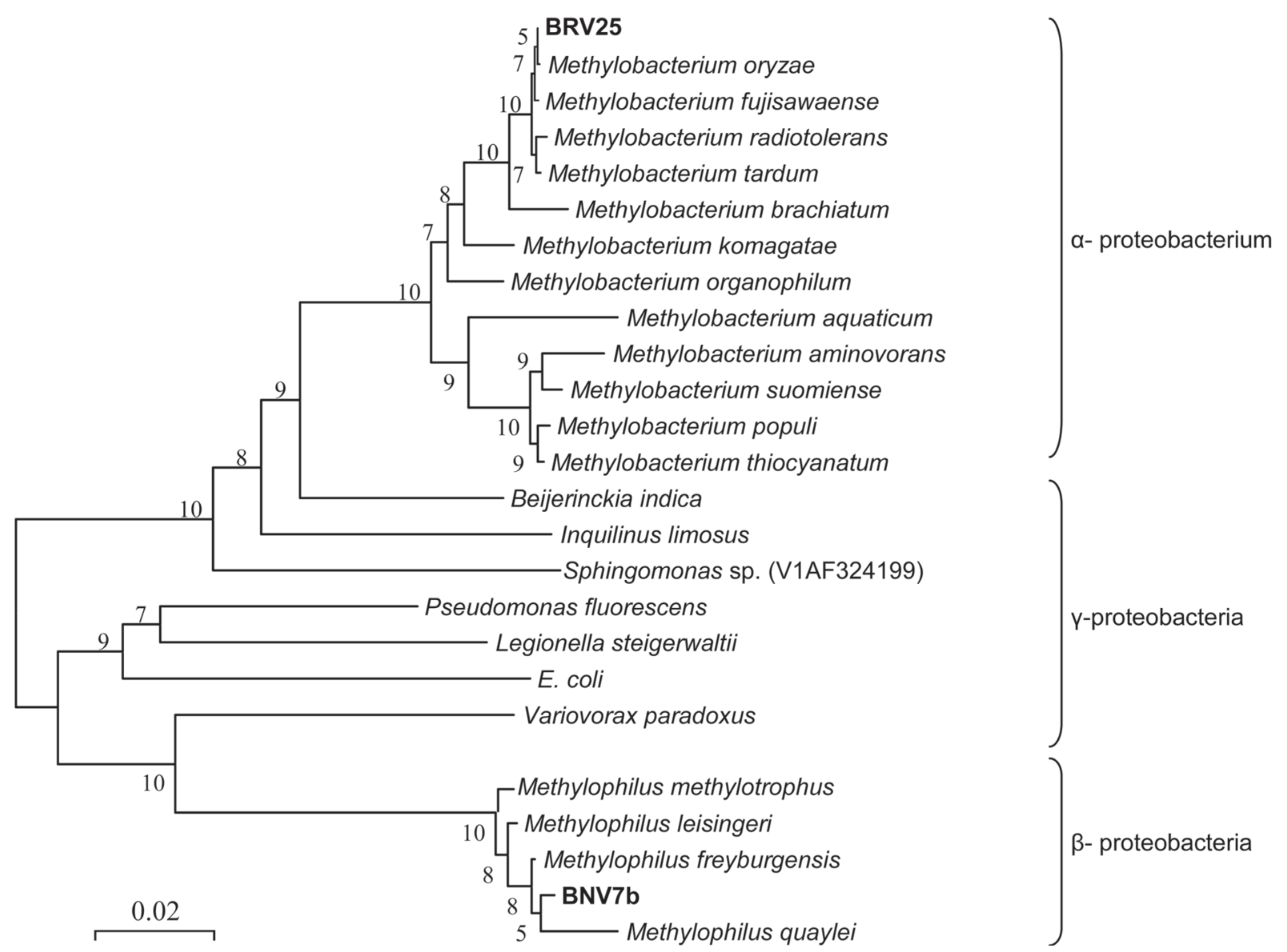

Fig. 1. Neighbor-joining phylogenetic tree showing the relationship between 16S rRNA gene sequences of methylotrophic strains isolated from coalmine spoil and their closest relative sequences retrieved from Gene bank database.

inhibitory. Both the strains tolerated SDS (2\%), but only Methylobacterium tolerated crystal violet $(0.01 \%)$ and $\mathrm{NaN}_{3}(0.02 \%)$.

Based on 16S r RNA gene sequence, strains BNV7b revealed 98\% similarity with Methylophilus freyburgensis and Methylophilus. quaylei whereas BRV25 formed a monophyletic clade having $99 \%$ similarity with Methylobacter oryzae which exhibited close relationship with Methylobacter fuisawanse and Methylobacter radiotolerans. Further, on their morphology, growth characteristics and biochemical tests revealed that strains BNV7b and BRV25 were the member of genera Methylophilus and Methylobacterium, respectively (Fig. 1).

Effect of $\mathrm{NaCl}$ on bacterial growth. In Methylobacterium sp. specific growth rate declined nearly $17 \%$ in $100 \mathrm{mM} \mathrm{NaCl}$ whereas this decline was as high as $75 \%$ in $500 \mathrm{mM} \mathrm{NaCl}$. In case of Methylophilus sp. there was no apparent change in specific growth in $100 \mathrm{mM} \mathrm{NaCl}$, but a decrease was nearly $16 \%$ and $86 \%$ in $200 \mathrm{mM}$ and $500 \mathrm{mM} \mathrm{NaCl}$, respectively (Fig. 2).

$\mathrm{Na}^{+}$uptake. Bacterial strains were treated with $200 \mathrm{mM} \mathrm{Na}{ }^{+}$and intracellular $\mathrm{Na}^{+}$estimated at $2 \mathrm{~h}$ interval till $6 \mathrm{~h}$ exhibited exponential and linear increasein Methylophilus and Methylobacterium sp., respectively (Fig. 3).
Electrolyte and organic solute leakage. In Methylophilus, electrolyte leakage was intense in $200 \mathrm{mM} \mathrm{NaCl}$ and marginal in $500 \mathrm{mM} \mathrm{NaCl}$. In contrast, there was concentration-dependent electrolyte leakage in Methylobacterium sp. A significant decrease in the cellular solute in both the bacterial sp. was observed though decrease was more in Methylophilus sp. The high level

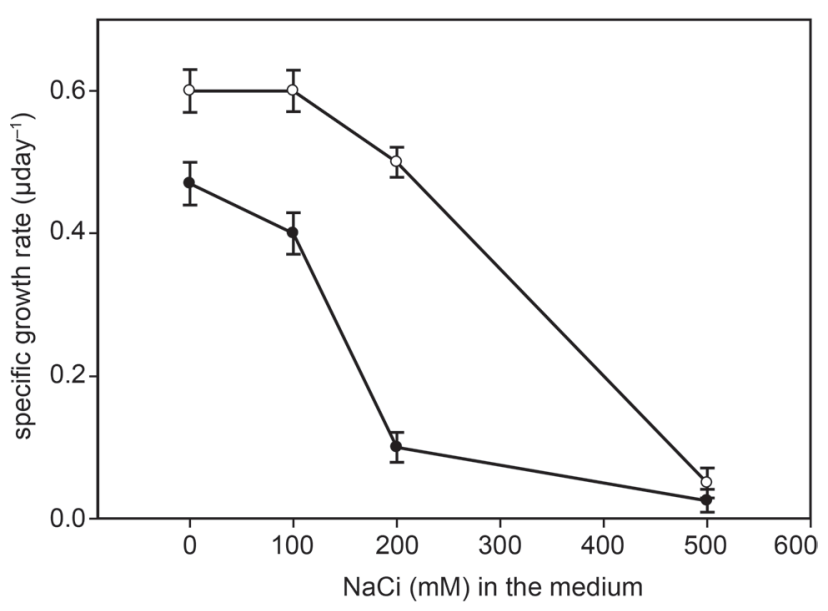

Fig. 2. Specific growth rate $\left(\mu\right.$ day $\left.^{-1}\right)$ of Methylophilus sp. BNV7b (--) and Methylobacterium sp. BRV25 (-O-) with $\mathrm{NaCl}$ concentrations in the medium. Data are mean \pm 1 SE of three replicates. 


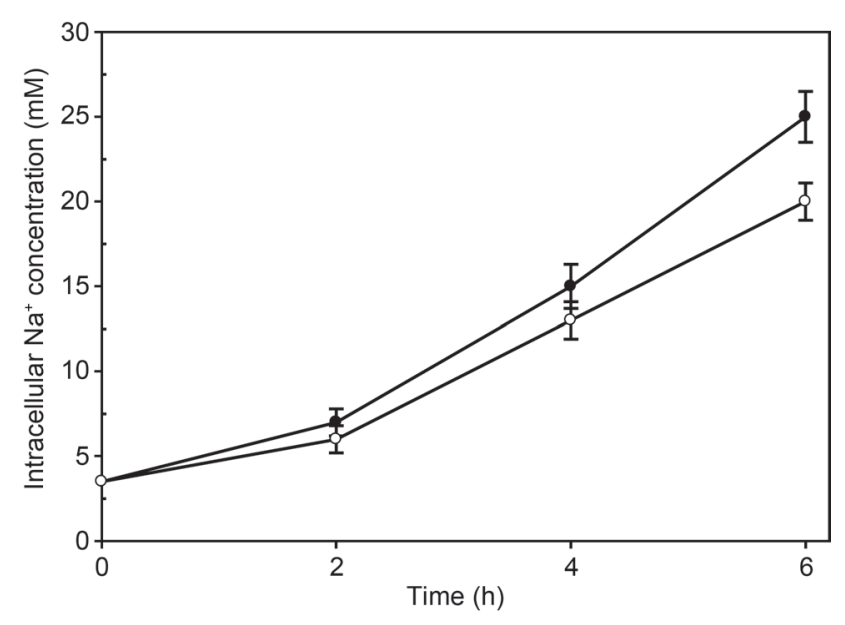

Fig. 3. Increase in intracellular $\mathrm{Na}^{+}$concentration content (a) and decrease in relative water content (b) of Methylophilus sp. BNV7b (-) and Methylobacterium sp. BRV25 (-O-) in $200 \mathrm{mM} \mathrm{NaCl}$ in the medium. Data are mean $\pm 1 \mathrm{SE}$ of three replicates.
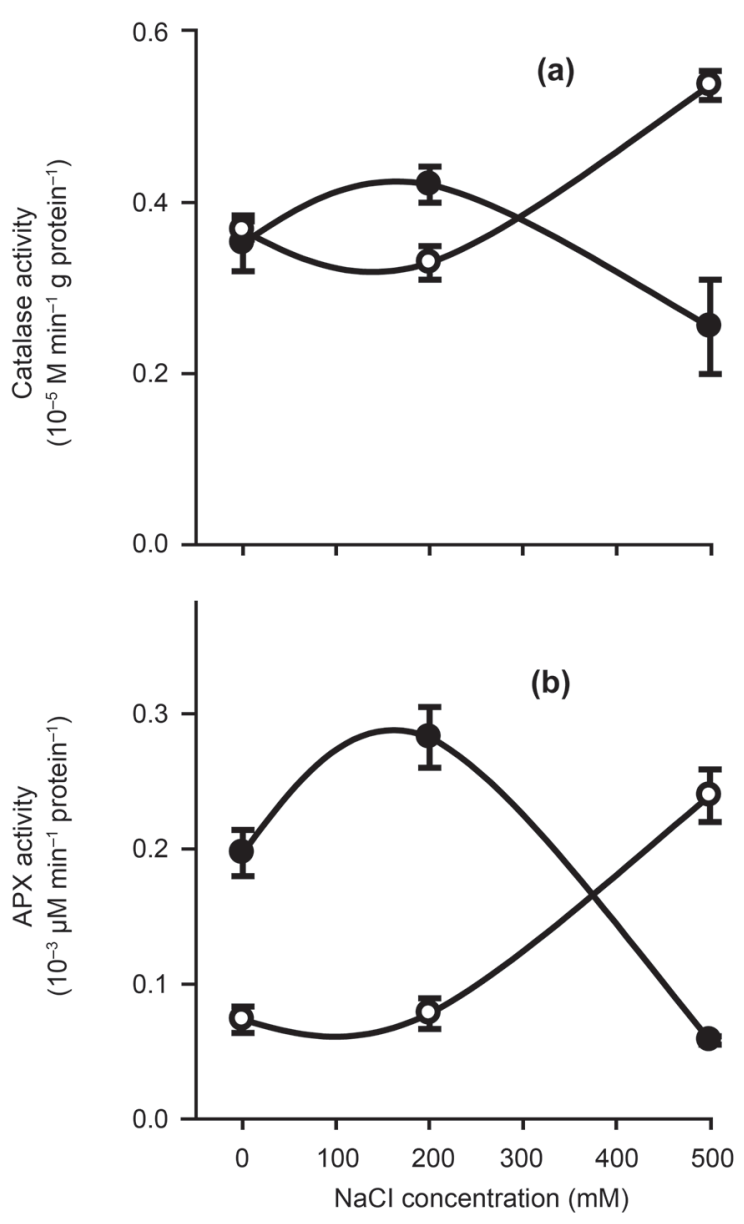

of leakage was noticed for amino acids, carbohydrate and carotenoids, while low leakage of RNA was noticed (data not shown).

Peroxide and malondialdehyde production. In $200 \mathrm{mM} \mathrm{NaCl}$, peroxide and malondialdehyde (MDA) production were also significantly higher in Methylophilus sp. as compared to Methylobacterium sp.
Antioxidative enzymes. The CAT activity of Methylobacterium sp. and Methylophilus sp. was almost same in control where as exhibited slight activation and suppression in the respective strains at $200 \mathrm{mM}$ salt, but its significant reverse result was observed in $500 \mathrm{mM}$ salt (Fig. 4a)

APX activity was less than half in Methylobacterium sp. compared to Methylophilus sp. in control. APX activity was nearly equal to control in $200 \mathrm{Mm}$ and increased three times in $500 \mathrm{mM} \mathrm{NaCl}$ in Methylobacterium sp. whereas in Methylobacterium sp. APX activity increased 1.4 times in $200 \mathrm{mM}$ and decreased to one third in $500 \mathrm{mM}$ salt compared to the control. (Fig. 4b)

In Methylobacterium SOD activity increased linearly up to $500 \mathrm{mM} \mathrm{NaCl}$ where as in Methylophilus sp. activity increased in $200 \mathrm{mM}$ and slightly decreased in $500 \mathrm{mM}$ compared to the control (Fig. 4c).

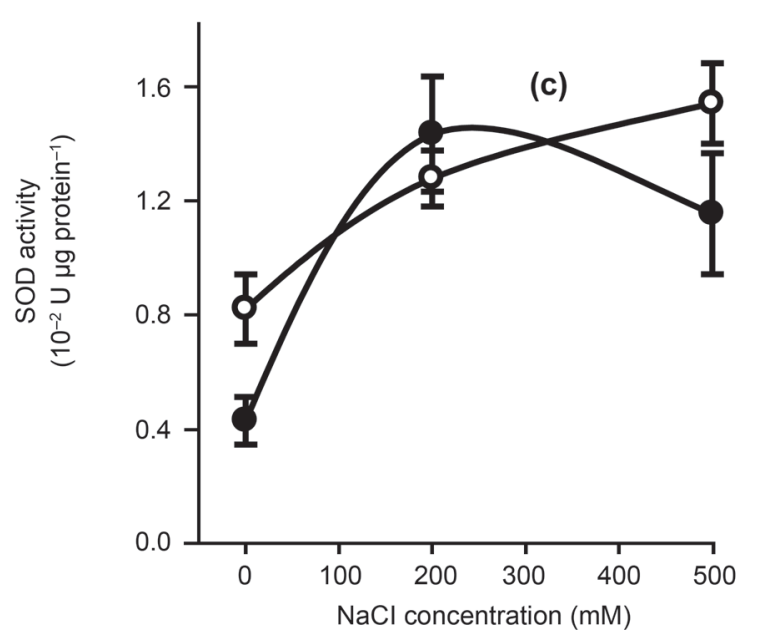

Fig. 4. Effect of $\mathrm{NaCl}(\mathrm{mM})$ on the enzyme (a) CAT (b) APX and (c) SOD on two methylotrophic strains Methylophilus sp. BNV7b (--) and Methylobacterium sp. BRV25 (-O-). Date represents mean \pm 1 SE of three replicates.

Cell viability. Cell viability remained nearly equal in $1.5 \mathrm{M} \mathrm{NaCl}$ and TTC reduction was recorded even in $2 \mathrm{M} \mathrm{NaCl}$ in both the strains (Fig. 5.)

Effect of osmoprotectants. Among the various osmoprotectants used proline was the most effective and betaine was the least effective in maintaining the cell viability in selected methylotrophs. Exogenous 


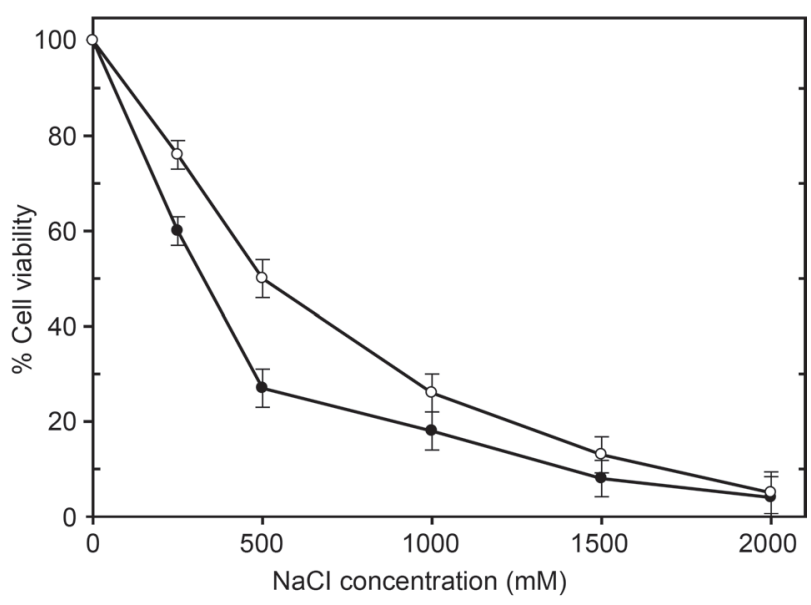

Fig. 5. Decrease in cellular viability (\%) of Methylophilus sp. BNV7b (-๑) and Methylobacterium sp. BRV25 (-O-) with increase in $\mathrm{NaCl}$ concentrations in the medium. Data are mean \pm 1 SE of three replicates.

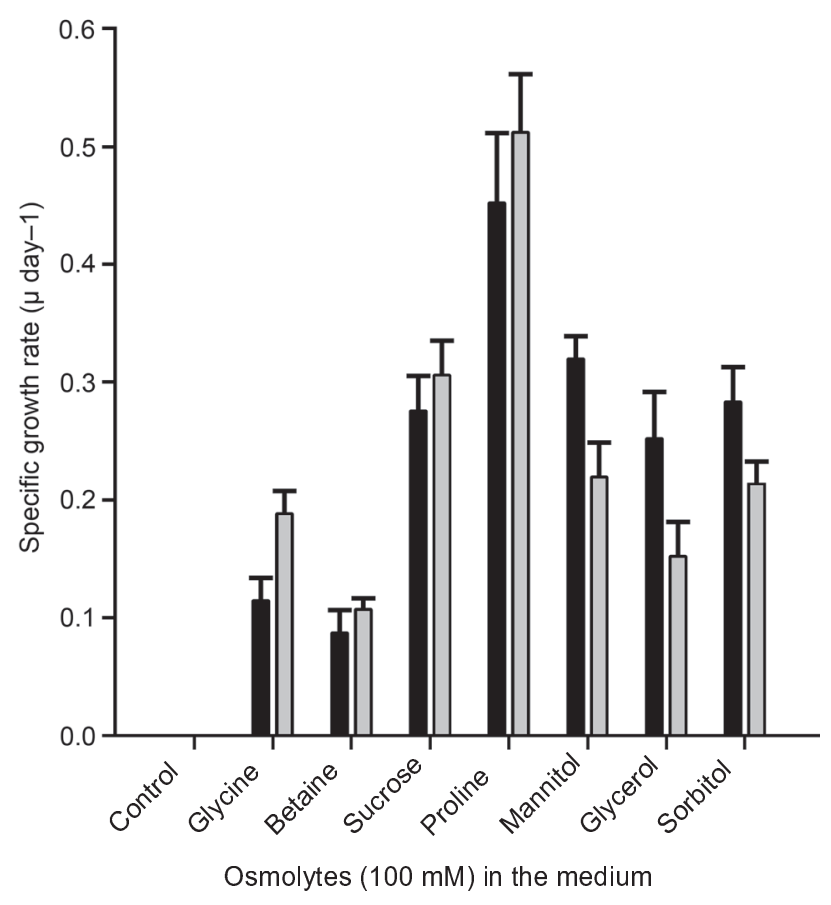

Fig. 6. Specific growth rate of methylotrophs, Methylophilus sp. BNV7b (Black bars) and Methylobacterium sp. BRV25 (light shaded bars), incubated with $100 \mathrm{mM}$ concentration of various osmoprotectants and $0.5 \mathrm{M} \mathrm{NaCl}$.

Data represented as mean $\pm 1 S E$ of three replicates.

betaine, glycine and proline were more effective in Methylobacterium sp., while glycerol, mannitol and sorbitol were effective in Methylophilus sp. (Fig. 6).

\section{Discussion}

The two selected methylotrophs, Methylophilus sp. and Methylobacterium sp. utilized a number of organic C compounds as the carbon source, differed with respect to inorganic and organic $\mathrm{N}$ utilization. Methylophilus utilized the combined inorganic $\mathrm{N}$ sources and amino acids whereas Methylobacterium relied mostly on inorganic N. These bacteria exhibited similarity in their lysis tolerance and differed in their response to chemical inhibitors. Methylobacterium sp. tolerated respiration inhibiting compounds azide and cell division inhibiting crystal violet (Walker et al., 1971), while Methylophilus was sensitive to both of them.

We observed up to $20 \%$ and $40 \%$ decreased relative water content in Methylobacterium and Methylophilous sp. respectively when grown in $200 \mathrm{mM} \mathrm{NaCl}$. Ronsch and coworkers (2003) grew Corynebacterium glutamic to study the influence of osmotic stress, when the cells grew in constant osmotic stress, the maximal cytoplasmic volume decreased significantly with increase in external osmolalities. Further, under severe osmotic stresses maximum cytoplasmic volume were lower and required long time period to attain the maximal cytoplasmic volume of non stressed cells. The critical threshold of $\mathrm{NaCl}$ was $400 \mathrm{mM}$ and concentration above it inactivated most of the enzymes due to perturbation of hydrophobic-electrostatic interaction necessary for protein integrity (Wyn Jones and Pollared, 1983). The decreased anti-oxidative enzyme activity of Methylophilous sp. in $500 \mathrm{mM} \mathrm{NaCl}$ can be explained in the same terms. Again, enzyme inactivation under salt stress depends upon bacterial capabilities of ions transport across membrane. Methylobacterium sp. was more efficient in managing influx and efflux of $\mathrm{Na}^{+}$; the apparent increased $\mathrm{Na}^{+}$accumulation in Methylophilus sp. was due to its failed regulation of $\mathrm{Na}^{+}$. When the methylotrophic bacteria were treated with $200 \mathrm{mM}$ $\mathrm{NaCl}$, such sudden hyperosmotic shift in the laboratory condition obviously did not resemble the conditions in their natural growth habitat. In suddenly altered salt in the environment the microbes immediately started to accumulate different ions from the environment but in long term prevailing salt stress they accumulated osmoprotectants available in the environment or synthesized them de novo inside the cell.

The methylotrophic bacteria Methylobacter sp. and Methylophilous sp. differed in their preferred antioxidant for growth revival under deleterious salt. The intracellular level of solutes was increased to regulate the cellular osmotic balance, but in extreme extracellular salt led to damage the cell wall resulting in drastic leakage of solutes (Korber et al., 1996). Electrolyte and organic solute leakage were more prominent in $500 \mathrm{mM}$ $\mathrm{NaCl}$ due to membrane instability and lipid peroxidation in the methylotrophs (Table I).

All microorganisms have their own genetic capabilities to regulate various enzymes under stress condition. Methylobacterium sp. and Methylophilous sp. variably expressed three anti-oxidative enzymes SOD, CAT and 
Table I

Influence of $\mathrm{NaCl}$ concentration on leakage of electrolyte and various cellular organic solutes

\begin{tabular}{|l|c|c|c|c|c|c|}
\hline & \multicolumn{3}{|c|}{ Methylophilous sp. } & \multicolumn{3}{c|}{ Methylobacterium sp. } \\
\hline $\mathrm{NaCl}(\mathrm{mM})$ & 0 & 200 & 500 & 0 & 200 & 500 \\
\hline Electrolyte leakage (\%) & $1.5 \pm 0.1$ & $2.8 \pm 0.1$ & $3.3 \pm 0.1$ & $0.8 \pm 0.1$ & $1.6 \pm 0.2$ & $2.2 \pm 0.2$ \\
\hline Cellular water (\%) & 98 & 65 & 54 & 97 & 88 & 72 \\
\hline Carbohydrate released (\%) & $8.2 \pm 1.1$ & $12.1 \pm 1.2$ & $32.3 \pm 1.4$ & $5.1 \pm 0.9$ & $6.2 \pm 1.0$ & $15.1 \pm 1.1$ \\
\hline Protein released (\%) & $0.1 \pm 0.01$ & $5 \pm 0.3$ & $10.5 \pm 0.6$ & $0.08 \pm .01$ & $3 \pm 0.1$ & $5.9 \pm 0.6$ \\
\hline Amino acid released (\%) & $4.1 \pm 0.1$ & $10.2 \pm 0.4$ & $38.3 \pm 0.5$ & $3.1 \pm 0.1$ & $8.1 \pm 0.5$ & $32.0 \pm 0.5$ \\
\hline Carotanoids released (\%) & $3.3 \pm 0.3$ & $10.3 \pm 0.8$ & $38 \pm 0.5$ & $5.2 \pm 0.4$ & $8.3 \pm 0.4$ & $2.3 \pm 0.2$ \\
\hline RNA released (\%) & $0.33 \pm 0.10$ & $1.34 \pm 0.20$ & $2.54 \pm 0.30$ & $0.25 \pm 0.10$ & $0.63 \pm 0.22$ & $1.71 \pm 0.22$ \\
\hline
\end{tabular}

APX in the absence of salt, and in $200 \mathrm{mM}$ and $500 \mathrm{mM}$ $\mathrm{NaCl}$. Methlophilus sp. the activity of two antioxidative enzymes APX and CAT was increased in $200 \mathrm{mM}$, and the activity of both enzymes decreased below the control in $500 \mathrm{mM}$. Only SOD activity remained higher compared to the control in $500 \mathrm{mM}$. Salt stress induced ROS acts as the signal for programmed cell death in prokaryotic cells (Ning et al., 2002). Oxdative stress induced membrane damage and excessive solute leakage are the primary factors responsible for decreased viability. Plasmolysis caused by salt stress may also result in cell death (Korber et al., 1996). In extreme salt concentration most cells die but a very small proportion of cells has the ability to survive. This cell viability decreased by $95 \%$ in Bacillus subtilis facing $500 \mathrm{mM}$ $\mathrm{NaCl}$ (Ikeuchi et al., 2003).

The compatible solutes have two important functions, first they increase the internal osmolality leading to redirection of water flux to after osmotic upshift and restore growth. The second function of compatible solute is to stabilize the native state of the globular cellular proteins. Exogenous proline and betaine mitigated detrimental effects of $\mathrm{Na}^{+}$(Okuma et al., 2000; Harinasut et al., 1988). Proline stimulates cell growth by improving metabolism, reduced oxidation of the lipid membranes and increased the antioxidative enzymes activities (Hoque etal., 2007). Under conditions of low and medium osmolality, the addition of betain did not accelerate growth nor changed the time at which maximum growth rate occurred. But under severe osmotic stress, the addition of betaine shortened the time required to reach the maximum growth (Ronsch et al., 2003). The methylotrophic genera selected in present when supplemented with various compatible solutes at $100 \mathrm{mM}$ concentration in the growth medium containing $500 \mathrm{mM} \mathrm{NaCl}$, specific growth rate was very lowest in betaine, highest in proline and intermediate for glycine and various polyols. This was due to the fact that proline acts as predominant compatible solute independent of constant higher osmolality (Ronsch et al., 2003) or sudden upshift (Guillouet and Engasser,
1996). However, proline accumulation is affected by the presence of other compatible solutes such as betaine. The intracellular proline was as high as $815 \mathrm{mM}$ and $300 \mathrm{mM}$ in the cytoplasm in the absence and presence of betaine, respectively. Pseudomonas putida produced mannitol in response to osmotic stress (Kets et al., 1996), though polyols are not a preferred compatible solute in bacteria. The presence of polyols like mannitol, glycerol and sorbitol in the extracellular environment was beneficial for methylotrophs in stress and provided better protection.

Microbial adaptation in a degraded habitat is a long term process and requires perhaps a decade (Wichern et al., 2006). In the heterogeneous habitat of coal mines spoils with multiple stress conditions like low water, high salt and nutrient limiting conditions, salinity tolerant pink pigmented methylotrophic bacteria Methylophilous sp. and Methylobacterium sp. attained high population size $\left(10^{4}\right.$ to $\left.10^{6}\right)$ in a time interval of four to 12 years (Giri et al., 2012), and are supposed to be adapted to such an environment. The Methylobacterium sp. in coal mine spoils could be of phyllospheric origin (Madhaiyan et al., 2001), adapted to stressed coal mine spoils.

\section{Acknowledgements}

The authors are thankful to the Head, Department of Botany for the basic laboratory facilities and CSIR, New Delhi for financial support.

\section{References}

Asada K. 1984. Chloroplasts: formation of active oxygen and its scavenging. Meth. Enzymol. 105: 422-435.

Beauchamp C. and I. Fridovich. 1971. Superoxide dismutase: improved assay and an assay applicable to acrylamide gels. Anal. Chem. 44: 276-287.

Bradford M.M. 1976. A rapid and sensitive method for the quantitation of microgram quantities of protein utilizing the principle of protein-dye binding. Anal. Chem. 72: 248-254.

Cakmak I. and J. Horst. 1991. Effect of aluminum on lipid peroxidation, superoxide dismutase, catalase and peroxides activities in root tips of soybean (Glycine max). Physiologia Plantarum 83: 463-468. 
Clairbone A. 1985. Catalase activity. In: Greenwald RA. (Ed.), Handbook of methods for oxygen radical research. CRC Press, Florida, pp. 283-284.

Ellis R.J., P. Morgan, A.J. Weightman and J.C. Fry. 2003. Cultivation-dependent approaches for determining bacterial diversity in heavy-metal-contaminated soil. Appl. Environ. Microbiol. 69: 3223-3230.

FAO. 2006. Global network on integrated soil management for sustainable use of salt-affected soils. FAO Land and Plant Nutrition Management Service, Rome [online] Available at URL: http://www. fao.org/ag/agl/agll/spush (April, 2009).

Fournier D., S. Trott, J. Hawari and J. Spain. 2005. Metabolism of the aliphatic nitramine 4-nitro-2, 4-diazabutanal by Methylobacterium sp. strain JS178. Appl. Environ. Microbiol. 71: 4199-4202.

Giri D.D., P.N. Shukla, Singh Ritu Ajay Kumar and K. D. Pandey. 2012. Substrate utilization of stress tolerant methylotrophs isolated from revegetated heavy metal polluted coalmine spoil. World J. Microbiol. Biotechnol. DOI 10.1007/s11274-012-1219-7

Gómez J.M., A. Jiménez, E. Olmos and F. Sevilla. 2004. Location and effects of long-term $\mathrm{NaCl}$ stress on superoxide dismutase and ascorbate peroxidase isoenzymes of pea (Pisum sativum cv. Puget) chloroplasts. J. Exptl. Bot. 55: 119-130.

Guillouet S. and J. M. Engasser. 1996. Growth of Corynebacterium glutamicum in ammonium and potassium-limited continuous cultures under high osmotic pressure. Appl. Microbiol. Biotechnol. 46: 291-296

Halliwell B. and J.M.C. Gutteridge. 1986. Oxygen free radicals and iron in relation to biology and medicine: some problems and concepts. Arch. Biochem. Biophy. 246: 501-514.

Hanson R.S. 1998. Ecology of methylotrophic bacteria. In: Burlage, RS, Atlas R, Stahl D, Geesey G, Sayler G (Eds.), Techniques in Microbial Ecology. Oxford University Press, New York, pp. 137-162. Harinasut P., T. Takabe, T. Akazawa, M. Tagaya, T. Fukui. 1988. Characterization of an ATPase associated with the inner envelope membrane of amylopasts from suspension cultured cells of sycamore Acer pseudoplantanus L. Plant Physiol. Sep 88: 119-24.

Hoque M.A., E. Okuma, N.A. Banu, Y. Nakamura, Y. Shimoishi, and Y. Murata. 2007. Exogenous proline mitigates the detrimental effects of salt stress more than exogenous betaine by increasing antioxidant enzyme activities. J. Plant. Physiol. 164: 553-561.

Ikeuchi T., A. Ishida, M. Tajifi and S. Nagata. 2003. Induction of salt tolerance in Bacillus subtilis IFO 3025. J. Biosci. Bioengg 96: 184-186.

Ivanova E., N. Doronina and Y. Trotsenko. 2007. Hansschlegelia plantiphila gen. nov. sp. nov., a new aerobic restricted facultative methylotrophic bacterium associated with plants. Syst. Appl. Microbiol. 30: 444-452.

Kamali M. and H. Manhouri. 1969. A modified orcinol reaction for RNA determination. Clinical Chemistry 15: 390-392.

Kets E.P.W., J.A.M. de Bont and H.J. Heipieper. 1996. Physiological response of Pseudomonas putida S12 subjected to reduced water activity. FEMS Microbiology Letters 139: 133-137.

Korber D.R., A. Choi, G.M. Wolfaardt and D.E. Caldwell. 1996. Bacterial plasmolysis as a physical indicator of viability. Appl. Environ. Microbiol. 62: 3939-3947.

Li R. and R.S. El-Mallakh. 2004. Differential response of bipolar andnormal control lymphoblastoid cell sodium pump to ethacrynic acid. J. Affective Disorders 80: 11-17.

Lutts S., J.M. Kinet and J. Bouharmont. 1996. NaCl-induced senescence in leaves of rice (Oryza sativa L.) cultivars differing in salinity resistance. Annals of Botany 78: 389-398.
Madhaiyan M., S. Poonguzhall, and T. Sa. 2001. Metal tolerating methylotrophic bacterium reduces nickel and cadmium toxicity and promotes plant growth of tomato (Lycopersicon esculentum L.). Chemosphere 69: 220-228.

Maness P.C., S. Smolinski, D.M. Blake, Z. Huang, E.J. Wolfrum, and W.A. Jacoby. 1999. Bactericidal activity of photocatalytic $\mathrm{TiO}_{2}$ reaction: toward an understanding of its killing mechanism. Appl. Environ. Microbiol. 65: 4094-4098.

Moore S. and W. H. Stein. 1948. Photometric ninhydrin method for use in the chromatography of amino acids. J. Biol. Chem. 176: 367-388.

Myers J. and W.A. Kratz. 1955. Relations between pigment content and photosynthetic characteristics in a blue green alga. J. Gen. Physiol. 39: 11-21.

Ning S.B., H.L. Guo, L. Wang and Y.C. Song. 2002. Salt stress induces programmed cell death in prokaryotic organism Anabaena. J. Appl. Microbiol. 93: 15-28.

Okuma E., K. Soeda, M. Tada and Y. Murata. 2000. Exogenous proline mitigates the inhibition of growth of Nicotiana tabacum cultured cells under saline conditions. Soil Sci. Plant Nutr. 46: 257-263. Pasamba EM, R.M. Demigillo and A.C. Lee. 2007. Antibiograms of pink pigmented facultative methylotrophic bacterial isolates from various sources. Philippine Scientist 44: 47-56.

Pathak H. and D.L.N. Rao. 1998. Carbon and nitrogen mineralization from added organic matter in saline and alkaline soils. Soil Biol. Biochem. 30: 695-702.

Robert H., C. Le Marrec, C. Blanco and M. Jebbar. 2000. Glycine, betaine, carnitine, and choline enhance salinity tolerance and prevent the accumulation of sodium to a level inhibiting growth of Tetragenococcus halophila. Appl. Environ. Microbiol. 66: 509-517.

Ronsch H., R. Krämer and S. Morbach. 2003. Impact of osmotic stress on volume regulation, cytoplasmic solute composition and lysine production in Corynebacterium glutamicum MH20-22B. J. Biotechnol. 4: 104: 87-97.

Sagisaka S. 1976. The occurrence of peroxide in perennial plant Populas gebrica. Plant Physiol. 57: 308-309.

Shamseldin A., J. Nyalwidhe and D. Werner. 2006. A proteomic approach towards the analysis of salt tolerance in Rhizobium etli and Sinorhizobium meliloti strains. Current Microbiol. 52: 333-339. Simard R.R. 1993. Ammonium acetate-extractable elements. In: Carter, M.R. (Ed.), Soil Sampling and Methods of Analysis, Canadian Society of Soil Science, Lewis Publishers, Boca Raton, pp. 39-42.

Sy A., E. Giraud, P. Jourand, N. Garcia, A. Willems, P. de Lajudie, Y. Prin, M. Neyra, M. Gillis, C. Boivin-Masson and B. Dreyfus. 2001. Methylotrophic Methylobacterium bacteria nodulate and fix nitrogen in symbiosis with legumes. J. Bacteriol. 183: 214-220.

Walker J.R., N.A. Shafiq and R.G.Allen. 1971. Bacterial cell division regulation: physiological effects of crystal violet on Escherichia coli ion+ and ion- strains. J. Bacteriol. 108: 1296-1303.

Wichern J., F.Wichern, and R.G.Joergensen.2006. Impact of salinity on soil microbial communities and the decomposition of maize in acidic soils. Geoderma 137: 100-108.

Wyn Jones R.G. and A. Pollard. 1983. Proteins, enzymes and inorganic ions. In: Lauchli, A., Bieleski, R.L. (Eds.), Inorganic plant nutrition: Encyclopedia of plant physiology. Springer, Berlin, pp. 28-562. Yellore D. 1998. Production of poly-3-hydroxybutyrate from lactose and whey by Methylobacterium sp. ZP24. Lett. Appl. Microbiol. 26: 391-394.

Yemm E.W. and A.J. Willism. 1954. The estimation of carbohydrates in plant extracts by anthrone. Biochemical J. 57: 508-514. 